\title{
Correlation Between Company Condition and Work Achievement Of Employees in PT. Plantation Nusantara IV Balimbingan Plantation
}

\author{
Muhammad Authar ND ${ }^{1 *}$, Anwar Puteh², Amelia Pane'1, Teuku Alfiady ${ }^{3}$ \\ ${ }^{I}$ Department of Agribusiness, Faculty of Agriculture, Universitas Malikussaleh, Aceh, Indonesia. \\ ${ }^{2}$ Department of Islamic Economics, Faculty of Economic and Business, Universitas Malikussaleh, Aceh, Indonesia \\ ${ }^{3}$ Department of Public Administration, Faculty of Social Science and Political Science, Universitas Malikussaleh, Aceh, Indonesia \\ *Corresponding author E-mail: muh.authar@unimal.ac.id
}

\begin{abstract}
The role of human resource management is reflected in the company's policy to regulate its human resources so that it can play a major role in working together and supporting the company's strategy by measuring the level of employee performance. Employee work performance is strongly influenced by the condition of company such as motivation factors, job satisfaction, working stress, physical condition of work, compensation system, and job design. The purpose of this study was to determine the relationship of motivation factors, job satisfaction, working stress, physical condition of work, compensation system, and job design with employee performance at PT. Perkebunan Nusantara IV Unit Kebun Balimbingan. This research was carried out at PT. Perkebunan Nusantara IV Unit Kebun Balimbingan in May 2018. This study uses non-parametric analysis with Kendall Tau test. The results showed that the factors of motivation, job satisfaction, work stress, physical condition of work, compensation system and job design were partially related to employee performance because of the significance value $(0.000<0.05)$. Motivation factors, job satisfaction, physical condition of work and compensation system are strongly related and the direction of a positive relationship with work performance is the correlation coefficient values of $0.895,0.720,0.733$ and 0.706 , respectively. Job stress factors are negatively related to work performance with a correlation coefficient value of -0.550 . Job design factors are positively related to a low correlation level of 0.377 . Simultaneously the six factors are significantly related to work performance because the value of Asymp.Sig $<0.05$.
\end{abstract}

Manuscript received 23 Feb 2021; revised 2 March. 2021; accepted 15 March 2021. Date of publication 2 April 2021

Keywords: Company, Employees, Human Resource.

\section{Introduction}

PT. Perkebunan Nusantara IV Balimbingan Plantation Unit is a company engaged in oil palm plantations which aims to become a company that excels in integrated agro-industry business activities. Even though it has become a large company, there are still many obstacles that must be faced, both from internal and external that affect work performance [1].

Balimbingan Gardens conduct evaluations in the form of work performance assessments to manage human resources to be more effective and able to increase the quantity of work. Employee performance appraisal is carried out with several aspects of assessment, namely attendance discipline, timeliness of task completion, accuracy of task completion results, teamwork and employee initiative. After the assessment, the company determines the class [2].

The determination of the group given by the company consists of four criterias, namely rank up, special periodic rise, ordinary periodica rise and regular periodic rise. Upgrading applies to employees who have very good assessment criteria. Special periodic rise is given to employees with good assessment criteria and these employees can be increased periodically by 2-3. Regular periodicals are given to employees with moderate assessment criteria and the employee periodically increase. The class still applies to employees who have less assessment criteria, for example employees who receive a written warning/call and leave outside the company's responsibility [3].

Based on the survey, the results of group determination in 2019-2021 are as follow: 
Table 1. Results of Employee Assessment Results in PT. Perkebunan Nusantara IV Balimbingan Plantation Unit

\begin{tabular}{|c|c|c|c|c|c|}
\hline No & Rating Result & $\begin{array}{c}\text { Year of } 2016 \\
\text { (Person) }\end{array}$ & $\begin{array}{c}\text { Percentage } \\
(\%)\end{array}$ & $\begin{array}{c}\text { Year of } 2017 \\
\text { (Person) }\end{array}$ & $\begin{array}{c}\text { Percentage } \\
(\%)\end{array}$ \\
\hline (1) & (2) & (3) & (4) & $(5)$ & (6) \\
\hline 1 & Rank Up & 123 & 25,31 & 102 & 24,00 \\
\hline 2 & Special Periodic Rise & 248 & 51,03 & 212 & 49,88 \\
\hline 3 & Regular Periodic Rise & 113 & 23,25 & 104 & 24,47 \\
\hline 4 & Remain & 2 & 0,41 & 7 & 1,65 \\
\hline & Total & 486 & 100 & 425 & 100 \\
\hline
\end{tabular}

Source: Secondary Data, 2020

Based on the table, it can be seen that there was a decrease in the classification of employees from 2016 to 2017. The percentage of employees who rose up in class from 2016 to 2017 decreased by $1.31 \%$, special periodic increases decreased by $1.15 \%$, regular periodic increases increased by $1,22 \%$ and the fixed group increased by $1.24 \%$. Employee performance is strongly influenced by company conditions such as motivation, job satisfaction, stress, physical conditions of work, compensation system, and job design [4].

Based on this work, the authors conducted a study to find out how big the relationship between company condition factors such as motivation, job satisfaction, job stress, work physical condition, compensation system, and job design with employee performance at PT. Perkebunan Nusantara IV Balimbingan Plantation Business Unit, Tanah Jawa District, Simalungun Regency [5].

\section{Literature Review}

\subsection{Work Performance}

According to [6], work performance is a result of work both quality and quantity owned by employees. In essence, work performance is something that is achieved by employees in carrying out their duties in accordance with established standards and criteria.

\subsection{Factors Affecting Employee Performance}

Factors that affect work performance [7], include:

a. Motivation

Motivation is a condition that encourages an individual's desire to carry out certain activities [8]. Motivation in a person is a force that manifests behavior in an effort to achieve positive self-satisfaction by approaching the object that is the goal.

b. Job Satisfaction

According to Moh. As'ad in [9] job satisfaction is an emotional state of employees in viewing their work. This can be seen in the positive attitude of employees towards the work done. Employees who do not have job satisfaction will lead to negative attitudes that will lead to frustration, otherwise satisfied employees will be able to work well, enthusiastically, actively, and can perform better than employees who do not get job satisfaction.

c. Stress Level

Defines stress as a condition that affects a person's emotions and thought processes [10]. Some of the causes of stress according to John Suprihanto [11] are physical causes including noise, fatigue, work shifts, jet-lag, temperature and humidity, workload and nature of work, new and unfamiliar situations, personal threats, work acceleration, ambiguity, feedback, freedom and difficulty.

d. Physical Condition of Work

The physical condition of an organization's work has an important role in the smooth production process because a good work environment can not only satisfy employees in carrying out their duties, but also has an effect on improving employee performance. Some factors related to the work environment according to [11] are employee relations, the level of noise in the work environment, work regulations, lighting, air circulation, and security.

e. Compensation System

According to [12] the compensation system is everything that employees receive as compensation for their work. Compensation given is in the form of money, material facilities, and career opportunities [13].

f. Job Design

Defines job design as the process of determining the tasks to be performed, the methods used to carry out these tasks, and how the work is related with other jobs in the organization [14].

\section{Methods}

\subsection{Research Site}

This research was conducted at PT. Perkebunan Nusantara IV Balimbingan Garden Unit, Tanah Jawa District, Simalungun Regency with the consideration that the Balimbingan Gardens Business Unit applies a work performance assessment system for its employees and there is a declining class determination from 2018 to 2020.

\subsection{Types and Source of Data}

This study uses 2 types of data, namely:

a. Primary data, namely data obtained from direct observation, interviews, and questionnaires which are distributed toto employees at PT. Perkebunan Nusantara IV Balimbingan Plantation Unit.

b. Secondary data, namely data obtained from books, online media, scientific publications (research journals) and company archives related to research. 


\subsection{Population and Sampling Techniques}

The population in this study were all employees who worked at the Balimbingan Gardens which consisted of 425 people as seen in Table 2 .

Table 2. Total Population of Executive Employees

\begin{tabular}{clc}
\hline No. & \multicolumn{1}{c}{ Afd./Bagian } & Total (Jiwa) \\
\hline$(1)$ & \multicolumn{1}{c}{$(2)$} & $(3)$ \\
\hline 1 & Afdeling I & 75 \\
2 & Afdeling II & 96 \\
3 & Afdeling III & 89 \\
4 & Afdeling IV & 80 \\
5 & Office of Plant Assistant & 11 \\
6 & Office of Head of Administration Assistant & 10 \\
7 & Nursery & 11 \\
8 & General HR and Security & 38 \\
9 & Teknical Department & 15 \\
\hline
\end{tabular}

Source: Secondary Data, 2020

According to [15], if the subject is less than 100 people, all of them can be samples; if the subject is larger or more than 100 people we can take $10-15 \%$ or $20-25 \%$ or more. In this study, $15 \%$ of the population was taken so that the number of samples was $15 \%$ x 425 employees $=64$ employees.

For sampling from the population used proportional random sampling technique. The formula used is as follows:

$$
n_{i}=\frac{N i}{N} \times n
$$

$\mathrm{n}_{\mathrm{i}}=$ Member proportion of each section

$\mathrm{N}_{\mathrm{i}}=$ population in each section

$\mathrm{N}=$ Total Population

$\mathrm{n}=$ Samples taken in research

Table 3. Total Population and Sample of Executive Employees

\begin{tabular}{clcc}
\hline No. & \multicolumn{1}{c}{ Afd./Section } & Total & Sample \\
\hline 1. & Afdeling I & 75 & $75 / 425 \times 64=11$ \\
2 & Afdeling II & 96 & $96 / 425 \times 64=14$ \\
3 & Afdeling III & 89 & $89 / 425 \times 64=13$ \\
4 & Afdeling IV & 80 & $80 / 425 \times 64=12$ \\
5 & Office of Plant Assistant & 11 & $11 / 425 \times 64=2$ \\
6 & Office of Head of Administration & 10 & $10 / 425 \times 64=2$ \\
& Assistant & 11 & $11 / 425 \times 64=2$ \\
7 & Nursery & 38 & $38 / 425 \times 64=6$ \\
8 & General HR and Security & 15 & $15 / 425 \times 64=2$ \\
9 & Teknical Department & 425 & 64 \\
\hline \multicolumn{2}{c}{ Total } & &
\end{tabular}

Source: Secondary Datar, (2020)

\subsection{Data Analysis}

The method used to analyze the data is quantitative analysis using Likert data measurement scale. The questionnaire was made with several alternative answers, where the questions were divided into a measuring scale, namely:

\begin{tabular}{lc}
\hline Choices & Scores \\
\hline Strongly Disgree & 1 \\
Disagree & 2 \\
Neutral & 3 \\
Agree & 4 \\
Strongly Agree & 5 \\
\hline
\end{tabular}

The data that has been collected will be analyzed non-parametrically with the help of the SPSS software application. Data analysis using SPSS software consists of 2 stages, namely testing data quality (Validity and Reliability) and testing hypotheses.

\subsubsection{Data Quality Test}

\section{a. Quality Test}

Validity test was conducted to measure the validity of a questionnaire. The validity of the questionnaire explains the extent to which the data collected does not deviate from the existing variables. The questionnaire is said to be valid with the value of Correlated Item-Total Correlation > 0.3.

b. Reliability Test

Reliability is done to measure a questionnaire which is an indicator of a variable. The questionnaire is be reliable if the respondents' answers to the questions are consistent and stable. In this study, reliability was tested using the SPSS version 22 program. The reliability criterion was the Cronbach Alpha value > 0.60. 


\subsubsection{Hypothesis Test}

The hypothesis in this study uses the associative hypothesis, where the hypothesis is made to see the relationship between the dependent variable and the independent variable. Using the Kendall Tau Correlation and Kendall's W Test (Kendall's Concordance).

a. Nonparametric Correlations

In this study, the calculation of the Kendall correlation was obtained with the help of the SPSS version 22 program by looking at the significant value which must be less than the alpha value of 0.05 . To see the high and low correlation between the independent variable and the dependent variable, it can be seen based on the table of correlation coefficient values from the Guilford Emperical Rules:

Table 4. Level of Closeness of Relationship between Variable X and Variable Y

\begin{tabular}{cc}
\hline Correlation Value & Notes \\
\hline $0,00 \leq 0,20$ & Very weak correlation \\
$\geq 0,20 \leq 0,40$ & Weak correlation \\
$\geq 0,40 \leq 0,70$ & Medium correlation \\
$\geq 0,70 \leq 0,90$ & Strongk correlation \\
$\geq 0,90 \leq 1,00$ & Strong correlation \\
\hline
\end{tabular}

b. Kendall's Concordance (Kendall's W Test)

Kendall's Concordance test tool (Kendall's W Test) is used to see how big the correlation is to the six independent variables (motivation, job satisfaction, job stress, work physical condition, compensation system, job design) together with the dependent variable (Job Achievement). . The relationship of the independent variable to the dependent variable is indicated by the value of Kendal's W and the level of significance by looking at the value of Asymp.Sig. If the Asymp.Sig value < alpha 0.05, then together the independent variables are significantly related to the dependent variable.

\section{Results and Discussion}

\subsection{Data Quality Test}

\subsubsection{Validity Test}

After testing the validity of all question items ( 24 question items) on each variable is valid, because the value of Corrected Item-Total Correlation $>0.3$.

\subsubsection{Reliability Test}

Table 5. Research Variable Reliability Test Results

\begin{tabular}{llcl}
\hline No & Variabel & $\begin{array}{c}\text { Cronbach's } \\
\text { Alpha }\end{array}$ & Kriteria \\
\hline 1 & Motivation & 0,782 & Reliable \\
2 & Job Satisfaction & 0,645 & Reliable \\
3 & Work Stress & 0,667 & Reliable \\
4 & Work Physical Condition & 0,657 & Reliable \\
5 & Compensation System & 0,635 & Reliable \\
6 & Work Desain & 0,709 & Reliable \\
\hline
\end{tabular}

Source: Primary Data, 2020

Based on Table 15, the variables of motivation, job satisfaction, job stress, physical condition of work, compensation system and job design have Cronbach's Alpha values > 0.6 which means that the six instruments are declared reliable or meet the requirements.

\subsection{Hypothesis Testing}

\subsubsection{Correlation between Motivation Variable $\left(\mathbf{X}_{1}\right)$ and Work Performance $(\mathbf{Y})$}

Based on the results of the study that the significance value of $0.000<0.05$, it can be stated that the motivation variable is significantly related to work performance. The correlation coefficient is 0.895 , which means that work motivation is strongly related to work performance. While the direction of the relationship is positive because the value of $r$ is positive, meaning that the higher the employee's work motivation, the higher his work performance. In this study, work motivation is seen from indicators of challenges, suggestions and ideas, rewards and good relations.

From the results of observations and interviews in the field, the average respondent revealed that there were challenges in doing every job because the company set a target in completing the work, namely in the plant section there was a wholesale basis for harvesters that had to be obtained per day, the administration section had to make a report on the work every day. Every day, the security department is responsible for all security tasks which include directing, and controlling in the office and garden environment as well as the technical section making reports on all forms of repair work every day.

The company also provides opportunities for employees to convey ideas for the betterment of the company. In addition, the company gives awards to employees who excel, such as providing incentives in accordance with the class of each employee and giving awards to employees who have served in the company for a long time, namely those who have worked for 25,30 , and 35 years by giving certificates, medals gold, and cash. The relationship between employees is also going well because in the company itself the employees are old employees who already know each other and live nearby so that social relations are well maintained. 


\subsubsection{Correlation between Job Satisfaction $\left(\mathbf{X}_{2}\right)$ and Work Performance $(\mathbf{Y})$}

Based on the results of the study that the significance value of $0.000<0.05$, it can be stated that the job satisfaction variable is significantly related to work performance. The correlation coefficient is 0.720 , which means that job satisfaction is strongly related to work performance. While the direction of the relationship is positive because the value of $r$ is positive, meaning that the higher the employee's job satisfaction, the higher the work performance. In this study, job satisfaction is seen from indicators of interest, working conditions, facilities and opportunities.

From the results of observations and interviews in the field, the average respondent revealed that the work being carried out was currently in accordance with his abilities, from the observations the researchers also saw that employees had been placed in sections according to their respective expertise.

Facilities and infrastructure that support work have not been fully fulfilled, for example, safety and health protection tools for both field employees and office employees, which are limited in number. Work saturation also occurs in employees, because many employees have been working for a long time with almost the same activities every day. Opportunities to act independently are also not fully obtained because in carrying out their duties employees always receive direction from the leadership and must follow the Company's Operating Standards.

\subsubsection{Correlation betwen Job Stress $\left(\mathbf{X}_{3}\right)$ and Work Performance $(\mathbf{Y})$}

Based on the results of the study, it was found that the significance value of $0.000<0.05$, it can be stated that the work stress variable is significantly related to work performance. The correlation coefficient is -0.550 which means that work motivation is moderately related to work performance. While the direction of the relationship is negative because the value of $r$ is negative, meaning that the higher the employee's work stress, the lower his work performance. In this study, indicators of work stress are seen from various things, namely: work environment, individual pressure, group pressure and organizational pressure.

From the results of observations and interviews in the field, the workload and task demands are not too heavy because every day employees do work oriented to the targets set by the company so that work does not pile up. However, some employees, especially harvesters in Afdeling IV, said that the workload was too heavy because the wholesale basis was not in accordance with the topographical conditions in the field. So that the achievement of performance is less than optimal when compared to other afdeling.

\subsubsection{Correlation between Variable of Work Physical Condition $\left(\mathbf{X}_{4}\right)$ and Work Performance (Y)}

Based on the results of the study that the significance value of $0.000<0.05$, it can be stated that the physical condition of the work variable is significantly related to work performance. The correlation coefficient is 0.733 , which means that the physical condition of the job is strongly related to work performance. While the direction of the relationship is positive because the value of $r$ is positive, meaning that the higher the work environment, the higher the work performance. In this study, the physical condition of the work is seen from the indicators of lighting, movement space, security and the environment. The workspace is well lit, with a wide range of motion so that the process of work activities goes well. The company provides security and health insurance for employees by implementing the OHS System, providing protective equipment and health insurance for employees with labor social security and BPJS. There is also a health room at the company location, and in each afdeling office there is a complete first aid kit.

\subsubsection{Correlation between Variable of Compensation System $\left(\mathbf{X}_{5}\right)$ and Woek Performance $(\mathbf{Y})$}

Based on the results of the study that the significance value of $0.000<0.05$, it can be stated that the compensation system variable is significantly related to work performance. The correlation coefficient is 0.706 , which means that the compensation system is strongly related to work performance. While the direction of the relationship is positive because the value of $r$ is positive, meaning that the higher the compensation given, the higher the work performance. In this study, the compensation system is seen from the indicators of salary, incentives, benefits and facilities.

The company provides salaries twice a month, namely large salaries and small salaries, the amount of which is in accordance with the class of each employee. The company provides incentives to employees who do overtime, the amount of which is also regulated according to the class of each employee. In addition, the company also gives bonuses to employees once a year which is usually 3-4 times the basic salary.

\subsubsection{Correlation between Variable of Work Design $\left(\mathbf{X}_{6}\right)$ and Work Performance (Y)}

Based on the results of the study that the significance value of $0.000<0.05$, it can be stated that the job design variable is significantly related to work performance. The correlation coefficient is 0.377 , which means that job design has a weak relationship with work performance. While the direction of the relationship is positive because the value of $r$ is positive, meaning that the higher the job design, the higher the work performance. In this study, the physical condition of work is seen from indicators of type of work, work variation, work procedures, and work quality standards.

Job design has a weak correlation because the company itself has a work phase whose routine is continuous, the lack of work variation makes employees more active at work. Often employees feel bored with routine work that is too monotonous, especially for employees who have worked for many years. The work system in the company is that even though the employees have been promoted, the type of work done remains the same. There is also a lack of previous training so that when one of the positions is vacant due to the retirement of the employee, the process of replacing the position will take a long time because the appropriate employee for the position has not been fulfilled.

\subsection{Kendall's Concordance Test}

Based on the results of the study, it can be seen that the Asymp.Sig value of $0.000<0.05$, which means that simultaneously the variables of motivation, job satisfaction, job stress, physical condition of work, compensation system and job design are significantly related to work performance 


\section{Conclusion}

Based on the research that has been done, the following conclusions are obtained:

a. Factors of motivation, job satisfaction, job stress, physical condition of work, compensation system and job design are partially significantly related to employee performance because the significance value is greater than the alpha value $(0.000<0.05)$.

b. Factors of motivation, job satisfaction, physical condition of work and compensation system have a strong and positive relationship with work performance, namely the correlation coefficient values are $0.895,0.720,0.733$, and 0.706 . Work stress factors are negatively related to work performance with a correlation coefficient of -0.550 . Job design factors have a positive relationship with a low correlation level of 0.377 .

c. Simultaneously the six factors are significantly related to work performance because the value of Asymp.Sig $<0.05$

\section{References}

[1] A. D. Putra, I. Yusuf, and U. A. Gani, "Studi Potensi Limbah Biomassa Kelapa Sawit Sebagai Pembangkit Listrik Tenaga Uap (Pltu) Di Pt. Perkebunan Nusantara Xiii Pks Parindu," Univ. Tanjungpura Pontianak, 2016.

[2] K. N. Aini and T. Ariefiantoro, "PENGARUH MOTIVASI, LINGKUNGAN KERJA DAN DISIPLIN KERJA TERHADAP KINERJA KARYAWAN PT. PERKEBUNAN NUSANTARA IX SEMARANG (Studi Pada Karyawan Bagian Produksi Karet Kebun Sukamangli di PT. Perkebunan Nusantara IX Semarang)," Solusi, vol. 16, no. 4, 2019, doi: 10.26623/slsi.v16i4.1672.

[3] Y. Zebua, "PENGARUH BUDAYA KERJA DAN PROMOSI JABATAN DALAM MENINGKATKAN KINERJA KARYAWAN PADA PT. PERKEBUNAN NUSANTARA III LABUHAN HAJI LABUHANBATU UTARA,” ECOBISMA (JURNAL Ekon. BISNIS DAN MANAJEMEN), vol. 7, no. 2, 2020, doi: 10.36987/ecobi.v7i2.1758.

[4] M. S. Arif, R. Durrotun Nasihien, and H. Sutowijoyo, "BIM Implementation in Mall Laves Project Construction Surabaya," Int. J. Eng. Sci. Inf. Technol., vol. 1, no. 2, 2021, doi: 10.52088/ijesty.v1i2.49.

[5] S. Rizal, M. Iqbal, and D. Handayani, "STRATEGI PENINGKATAN PRODUKTIVITAS KARYAWAN PADA PT PERKEBUNAN NUSANTARA XIV (PABRIK GULA TAKALAR),” J. Ekon. Balanc., vol. 16, no. 1, 2020, doi: 10.26618/jeb.v16i1.3475.

[6] M. I. Birsyada, "Sufism ethics in Javanese aristocracy: A historical perspective," Int. J. Innov. Creat. Chang., vol. 11, no. 10, 2020.

[7] H. Murti and V. A. Srimulyani, "Pengaruh Motivasi Terhadap Kinerja Pegawai Dengan Variabel Pemediasi Kepuasaan Kerja Pada Pdam Kota Madiun," JRMA J. Ris. Manaj. dan Akunt., 2013.

[8] "PENERAPAN IPTEK USAHA PEMBUATAN TAHU DAN TEMPE DI BANDUNGAN KABUPATEN SEMARANG," Rekayasa, vol. 12, no. 1, 2014, doi: 10.15294/rekayasa.v12i1.5583.

[9] K. Nufus, A. Muchtar, H. Supratikta, and ..., "Analysis of Financial Performance: Case Study of Pt. X Employee Cooperative/Analisis del desempeno financiero: Estudio de caso de la cooperativa de empleados ...," Utopía Y Prax. ..., 2020.

[10] "PENGARUH PELATIHAN DAN KOMPENSASI TERHADAP PRESTASI KERJA PEGAWAI TVRI STASIUN SULUT," $J$. EMBA J. Ris. Ekon. Manajemen, Bisnis dan Akunt., vol. 6, no. 1, 2018, doi: 10.35794/emba.v6i1.19122.

[11] S. Riadi and E. Emzir, "SUFISTIC AND TRANSFORMATIVE PEDAGOGIC VALUES IN SYAIKH SITI JENAR NOVEL BY AGUS SUNYOTO GENETIC STRUCTURALISM," IJLECR - Int. J. Lang. Educ. Cult. Rev., vol. 1, no. 1, 2015, doi: 10.21009/ijlecr.011.08.

[12] Y. Handoko, N. Toni, and E. N. Simorangkir, "The Effect of Tax Knowledge and Tax Sanctions on Taxpayer Compliance at the Tax Office (KPP) Pratama, Medan Timur through Tax Awareness as an Intervening Variable,” Int. J. Res. Rev., vol. 7, no. 9, 2020.

[13] F. Ardiantika, "ANALISIS DISIPLIN PEGAWAI NEGERI SIPIL BERDASARKAN PERATURAN PEMERINTAH NOMOR 53 TAHUN 2010 TENTANG DISIPLIN PEGAWAI NEGERI SIPIL DI BADAN PEMBERDAYAAN PEREMPUAN DAN KELUARGA BERENCANA KABUPATEN LAMPUNG SELATAN,” Feby Ardiantika Putri, no. 53, 2015.

[14] S. Romadhona, F. Kurniawan, and J. Tistogondo, "Project Scheduling Analysis Using the Precedence Diagram Method (PDM) Case Study: Surabaya's City Outer East Ring Road Construction Project (Segment 1)," Int. J. Eng. Sci. Inf. Technol., vol. 1, no. 2, 2021, doi: 10.52088/ijesty.v1i2.56.

[15] S. Kumari and A. Harikrishnan, "Importance of Financial literacy For Sustainable Future Environment: A Research Among People In Rural Areas With Special Reference To Mandi District,Himachal Pradesh,” Int. J. Eng. Sci. Inf. Technol., vol. 1, no. 1, 2021, doi: 10.52088/ijesty.v1i1.36. 